\title{
Transfer of Some Saccharolytic Moraxella Species to Kingella Henriksen and Bøvre 1976, with Descriptions of Kingella indologenes sp. nov. and Kingella denitrificans sp. nov.
}

\author{
J. J. S. SNELL AND S. P. LAPAGE \\ National Collection of Type Cultures, Central Public Health Laboratory, Colindale, NW9 5HT, \\ London, England
}

\begin{abstract}
A new genus, Kingella, was recently proposed by Henriksen and Bøvre (1976) to accomodate the species previously named Moraxella kingae. We propose the inclusion of two further catalase-negative, oxidase-positive, saccharolytic species in this genus: $K$. indologenes sp. nov., comprising the saccharolytic strains described by van Bijsterveld (1970) and Sutton et al. (1972), type strain NCTC 10717 , and $K$. denitrificans sp. nov., comprising strains of the TM1 group described by Hollis et al. (1972), type strain NCTC 10995. The range of the guanine plus cytosine contents of the deoxyribonucleic acids from the three species in the genus Kingella is 47.3 to $54.8 \mathrm{~mol} \%$. Two other catalase-negative, oxidase-positive species, Eikenella corrodens and Cardiobacterium hominis, differed in phenotypic characters and in deoxyribonucleic acid base composition from the Kingella species.
\end{abstract}

Moraxella kingii was described and named by Henriksen and Bøvre (11), who thought this species was only distantly related to other $M o r-$ axella species, but who could suggest no other genus suitable for its inclusion. The specific epithet was corrected to kingae by Bøvre et al. (5), and recently Henriksen and Bøvre (12) proposed the transfer of $M$. kingae to a new genus, Kingella. This species differs from Moraxella species in failing to produce catalase and in its saccharolytic activity. Streptomycin-resistance transformation experiments (11) and pulse-labeled ribonucleic acid-deoxyribonucleic acid (RNA-DNA) hybridization experiments (2) have demonstrated lack of genetic homology between $K$. kingae and Moraxella species. The DNA base composition of $K$. kingae (47.3 to 47.4 mol\% guanine plus cytosine $[\mathrm{G}+\mathrm{C}]$ ) is also higher than that of Moraxella species (22).

Apart from $K$. kingae, two named saccharolytic species and two unnamed saccharolytic organisms have been classified in the genus Moraxella. The single extant strain of Moraxella saccharolytica Flamm 1956 (9) has a DNA

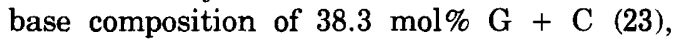
which is lower than the range of 42.8 to 44.6 $\mathrm{mol} \% \mathrm{G}+\mathrm{C}$ for Moraxella species (3, and vide infra), and it has been suggested that this species should be classified in the genus Flavobacterium $(10,16)$.

The reported characters of Moraxella amylolytica Chiu, Ho, and Lai 1966 (7) suggest that this species is more closely related to the genus Moraxella sensu stricto, i.e., catalase positive and non-saccharolytic. Attempts to obtain a strain of $M$. amylolytica from the original authors have been unsuccessful, and strains of this organism are not available from culture collections. Therefore, the taxonomic position of this species remains questionable.

van Bijsterveld (1) and Sutton et al. (24) described two unnamed saccharolytic strains which were shown by Bøvre et al. (4) to be nearly identical in their characters. Transformation and hybridization data are not available for these strains, but the DNA base composition $(48.7 \mathrm{~mol} \% \mathrm{G}+\mathrm{C})$ is higher than that of other Moraxella species (23).

Hollis et al. (14) described a group of saccharolytic strains, designated as TM1, which they regarded as belonging to an unnamed Moraxella species showing most similarity to $M$. kingii (sic). Transformation, hybridization, and DNA base composition data were not published for these strains by the authors.

In common with $K$. kingae, the Bijsterveld/ Sutton and TM1 strains are oxidase positive and catalase negative. This is an unusual combination of characters, and it is shared with the saccharolytic species Cardiobacterium hominis Slotnick and Dougherty 1964 (22) and the nonsaccharolytic species Eikenella corrodens (Eiken) Jackson and Goodman 1972 (15).

In the present study, representative strains of these organisms were examined in a range of phenotypic tests, and DNA base compositions were estimated. The results were compared with those obtained with strains of $K$. kingae, 
various Moraxella species sensu stricto, which are catalase positive, and Branhamella species in an attempt to clarify the taxonomic position of these catalase-negative, oxidase-positive strains.

\section{MATERIALS AND METHODS}

Bacterial strains. The culture-collection strains and field strains examined are listed in Table 1.

Characterization tests. Most of the media and methods used are based on those described by Cowan (8) and further described by Snell et al. (23), with additional tests as noted below. Incubation was at $37^{\circ} \mathrm{C}$ except where indicated otherwise.

Sensitivity to sodium chloride was determined by incorporating sodium chloride at concentrations of 4 and $6 \%$ into $5 \%$ horse blood agar plates. Saline suspensions of growth from overnight cultures on serum agar slopes were streaked on to the surface of the sodium chloride blood agar. Presence or absence of growth was recorded after 2 days of incubation. Hydrogen sulfide was detected by lead acetate paper strips over serum-nutrient broth cultures incubated for 5 days. Tween hydrolysis was detected by adding
Tween 20,40 , or 80 at concentrations of 0.2 and $0.5 \%$ ( $\mathrm{vol} / \mathrm{vol}$ ) to nutrient agar containing $0.01 \%(\mathrm{wt} / \mathrm{vol})$ calcium chloride. Plates were streaked with saline suspensions of bacteria, and hydrolysis of the Tweens was indicated by a precipitate in the medium surrounding the growth after 5 days of incubation.

Deoxyribonuclease production was detected by incorporating DNA (calf thymus) in serum-nutrient agar plates at a concentration of $0.2 \%(\mathrm{wt} / \mathrm{vol})$. Plates were streaked with saline suspensions of bacteria, and deoxyribonuclease production after 5 days of incubation was indicated, after flooding the surface of the medium with $1 \mathrm{~N}$ hydrochloric acid, by clear zones surrounding the bacterial growth. Penicillin susceptibility was detected by the presence of zones of inhibition of semiconfluent growth surrounding a paper disk containing 1 international unit (IU) of penicillin G on the surface of a blood agar plate. The production of acid from carbohydrates was tested for in the "sugars for neisserias" medium described by Cowan $(8$, p. 147) and in $\mathrm{O} / \mathrm{F}$ medium and phenol red broth base (Difco), both supplemented with $5 \%$ ( $\mathrm{vol} / \mathrm{vol})$ horse serum.

DNA base compositions. DNA was extracted by

TABLE 1. Strains examined in this study ${ }^{a}$

\begin{tabular}{lll}
\hline \multicolumn{1}{c}{ Strain } & Status & \multicolumn{1}{c}{ Source } \\
\hline Kingella kingae Henriksen and bøvre (synonym: Moraxella kingae) & & Holotype \\
NCTC 10529 (ATCC 23330; Henriksen and Bøvre 4177/66) & Nose swab \\
NCTC 10745 (ATCC 23331; Henriksen and Bøvre 2941) & Blood \\
NCTC 10746 (ATCC 23332; Henriksen and Bøvre 5530) & Blood \\
A241/71 & Blood \\
A7/75 (Frederiksen 440012) & Blood
\end{tabular}

Kingella indologenes sp. nov. (strains of van Bijsterveld [1] and Sutton et al. [24])

NCTC 10717 (ATCC 25869; strain of van Bijsterveld)

NCTC 10883 (strain of Sutton et al. [24])

$\begin{array}{ll}\begin{array}{c}\text { Designated } \\ \text { type }\end{array} & \text { Conjunctivitis } \\ & \text { Eye infection }\end{array}$

Designated Pharynx type

Pharynx

Stomatitis

Pharynx

NCTC 10997
A360/72 (Weaver B 4630)

Eikenella corrodens (Eiken) Jackson and Goodman 1972 (15) NCTC 10596 (ATCC 23834; Henriksen 333/54-55)

A40/68

A124/68

A13/69

A58/69

Cardiobacterium hominis Slotnick and Dougherty 1964 (22)

NCTC 10426 (ATCC 15826; Slotnick 6573)

NCTC 10427 (ATCC 15827; Slotnick 6574)

NCTC 10666 (Statens Seruministitut 1742/1966)

$\mathrm{A} 80 / 67$

$\mathrm{A} 13 / 68$

a Abbreviations: ATCC, American Type Culture Collection; NCTC, National Collection of Type Cultures. Strain numbers prefixed by the letter A, e.g., A241/71, are numbers used by the NCTC for strains sent for identification; they are not deposited strains. 
the method of Marmur (19) and was further purified by treatment with protease and phenol as described by Brenner et al. (6). The $T_{m}$ determinations were made in standard saline citrate buffer in a Pye Unicam SP 1800 spectrophotometer equipped with an electrically heated cell holder and a temperature programmer. The temperature of the DNA was raised at $0.25^{\circ} \mathrm{C}$ per min, and absorbance was recorded on a Pye Unicam AR 25 series linear strip chart recorder. The temperature of the DNA solution was measured at $0.5^{\circ} \mathrm{C}$ intervals with a thermistor bead inserted in the sample cuvette and with a temperature-reading meter. The thermistor bead and meter were calibrated against a thermometer, calibrated at the National Physical Laboratories, immersed in an oil bath to a depth of $8 \mathrm{~cm}$.

The equation used to relate $T_{m}$ to $\mathrm{mol} \% \mathrm{G}+\mathrm{C}$ was that of Mandel et al. (18): $\mathrm{mol} \% \mathrm{G}+\mathrm{C}$ unknown $=\mathrm{mol} \% \mathrm{G}+\mathrm{C}$ reference strain + [slope of equation $\times\left(T_{m}\right.$ unknown $-T_{m}$ reference strain $\left.)\right]$.

The slopes of the equations of Marmur and Doty (20) and of de Ley (17), which are both 2.44 , were used, and the average $T_{m}$ value from 11 determinations of the reference strain, Escherichia coli K-12 $(\mathrm{G}+\mathrm{C}=51 \mathrm{~mol} \%)$, was $91.51^{\circ} \mathrm{C}$. Substituting in the above equation gives: $\mathrm{mol} \% \mathrm{G}+\mathrm{C}=51+[2.44 \times$ $\left.\left(T_{m}-91.51\right)\right]$.

\section{RESULTS}

Microscopically, all 21 strains consisted of nonmotile, gram-negative rods. The strains of $K$. kingae and of the TM1 group showed both ovals and rods, with a high percentage of cells unevenly stained. The Bijsterveld/Sutton strains showed more regular, longer, evenly stained rods (Fig. 1).

After $48 \mathrm{~h}$ of incubation, the colonies formed on blood agar were convex and translucent and from 0.5 to $1.0 \mathrm{~mm}$ in diameter. The Bijsterveld/Sutton strains showed slightly more luxuriant growth than did the other strains. Pitting of the media and spreading edges of the colonies were observed in two strains of $K$. kingae, one strain of the TM1 group, and all five strains of $E$. corrodens. Although pitting was not observed around the colonies of the Bijsterveld/ Sutton strains, the original description of these strains $(1,24)$ indicated that pitting was present. It appears that this property was lost during the storage of these strains in our laboratory. The colonies were butyrous in consistency and were easily emulsified in saline. Marked $\beta$ hemolysis was observed with all strains of $K$. kingae. All strains grew at 30 and $37^{\circ} \mathrm{C}$ aerobically and anerobically on blood agar. None grew at 5 or $45^{\circ} \mathrm{C}$. All cultures became nonviable at $37^{\circ} \mathrm{C}$ after about 4 days and survived about 7 days at room temperature.

The biochemical characters of the strains, summarized in Tables 2 through 4 , shows that $K$. kingae, $C$. hominis, $E$. corrodens, and the
TM1 and Bijsterveld/Sutton strains were all distinct and recognizable from each other. $E$. corrodens differed markedly from the other strains in lacking saccharolytic activity and in producing lysine and ornithine decarboxylase.

DNA base compositions. The DNA base compositions of representative strains are shown in Table 5 together with values obtained in the National Collection of Type Cultures (NCTC) for various Moraxella spp. Recent work at the NCTC has indicated that a possible source of temperature-calibration error may cause differences in $T_{m}$ values between laboratories. Changes in the method of temperature calibration in the NCTC and the use of an
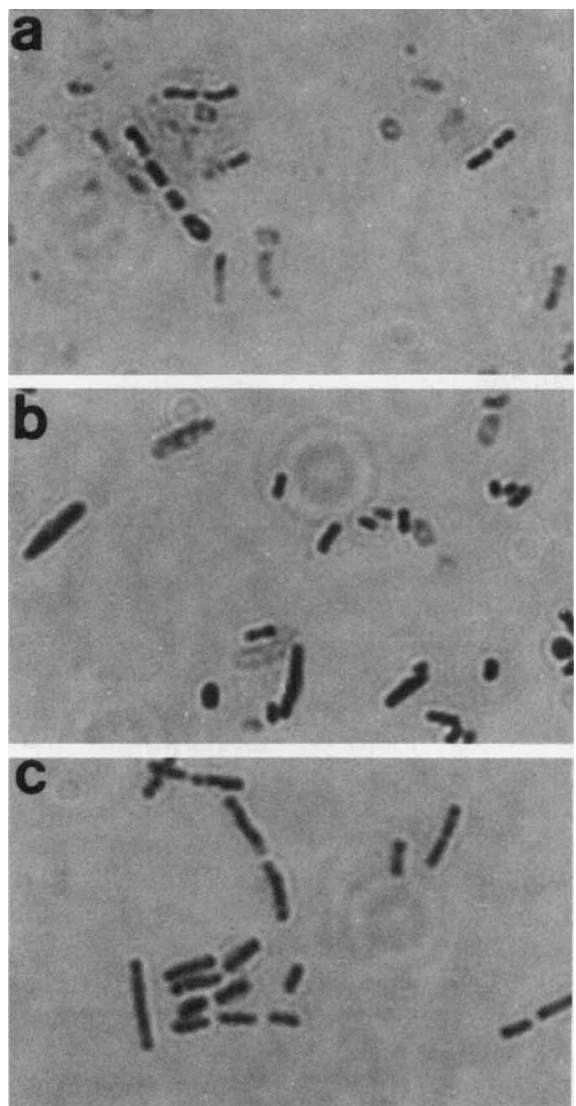

FIG. 1. Photomicrographs of overnight, Gramstained cultures. Magnification, $\times 2,000$. (A) K. kingae NCTC 10529, (B) $K$. denitrificans NCTC 10995 , (C) $K$. indologenes NCTC 10717.

Table 2. Tests positive for all strains

Anaerobic growth on blood agar

Growth at $30^{\circ} \mathrm{C}$

Growth at $37^{\circ} \mathrm{C}$

Oxidase production 
TABLE 3. Tests negative for all strains

\begin{tabular}{l} 
Growth at $5^{\circ} \mathrm{C}$ \\
Growth at $45^{\circ} \mathrm{C}$ \\
Growth on $6 \% \mathrm{NaCl}$ \\
Stimulation by bile \\
Motility \\
Catalase production \\
Gelatin liquefaction \\
Serum liquefaction \\
$\beta$-Galactosidase production \\
Citrate utilization \\
Growth in mineral medium with $\beta$-hydroxybutyrate \\
Poly- $\beta$-hydroxybutyrate granule production (nutri- \\
ent medium) \\
Urease production \\
Tween 80 hydrolysis \\
Lecithinase production \\
Arginine hydrolysis \\
Acid production from: \\
Adonitol \\
Arabinose \\
Cellobiose \\
Dulcitol \\
Ethanol \\
Galactose \\
Glycerol \\
Inositol \\
Lactose \\
Mannitol \\
Raffinose \\
Rhamnose \\
Salicin \\
Trehalose \\
Xylose \\
\hline
\end{tabular}

equation which relates the experimental values to the $T_{m}$ and $\mathrm{mol} \% \mathrm{G}+\mathrm{C}$ of $E$. coli $\mathrm{K}-12$ explain the differences of up to $2 \mathrm{~mol} \% \mathrm{G}+\mathrm{C}$ between the values given in this study for $E$. corrodens, $C$. hominis, and $K$. kingae and the values given in previous publications from the NCTC $(13,23)$.

The values of $\mathrm{mol} \% \mathrm{G}+\mathrm{C}$ given in this study are somewhat higher than estimates derived from buoyant-density measurements by Bøvre et al. (3), who based their results on a value of $50 \mathrm{~mol} \% \mathrm{G}+\mathrm{C}$ for $E$. coli $\mathrm{K}-12$. In the present work, a value of $51 \mathrm{~mol} \% \mathrm{G}+\mathrm{C}$ is assumed for $E$. coli $\mathrm{K}-12$, and the addition of $1 \mathrm{~mol} \% \mathrm{G}+\mathrm{C}$ to the Bøvre et al. (3) estimates reduces the differences to between 1 to $2 \mathrm{~mol} \% \mathrm{G}+\mathrm{C}$.

Although estimates of mol\% $\mathrm{G}+\mathrm{C}$ may vary between laboratories, results within a laboratory are extremely reproducible. Of the duplicate $T_{m}$ values estimated in this laboratory on 42 strains of Moraxella and related bacteria, five of the duplicate estimates agreed exactly, 11 agreed within $0.05^{\circ} \mathrm{C}, 21$ agreed within $0.1^{\circ} \mathrm{C}$, and five agreed within $0.2^{\circ} \mathrm{C}$.

The mol\% $\mathrm{G}+\mathrm{C}$ values of the catalasenegative, oxidase-positive strains (47.3 to 60.2 $\mathrm{mol} \% \mathrm{G}+\mathrm{C}$ ) were higher than those of the Moraxella species sensu stricto (catalase positive) (42.8 to $44.6 \mathrm{~mol} \% \mathrm{G}+\mathrm{C}$ ). At the lower end of the range for the catalase-negative, oxidase-positive strains, $K$. kingae and the Bijsterveld/Sutton strains had similar $\mathrm{mol} \% \mathrm{G}+\mathrm{C}$ values (47.3 to 47.4 and 48.7 , respectively), which overlapped the range for the so-called "false neisserias" (Branhamella catarrhalis, $B$. cuniculi, B. ovis, and B. caviae [41.8 to 47.3 $\mathrm{mol} \% \mathrm{G}+\mathrm{C}])$. C. hominis was clearly distinct from all the other strains with a $\mathrm{mol} \% \mathrm{G}+\mathrm{C}$ of 58.7 to 60.2 ; the TM1 strains and $E$. corrodens shared intermediate values ( 54.1 to 54.8 and 55.6 , respectively).

\section{DISCUSSION}

$K$. kingae and the Bijsterveld/Sutton strains appeared similar in phenotypic tests results, and their DNA base compositions differed by only 1.3 to $1.4 \mathrm{~mol} \% \mathrm{G}+\mathrm{C}$. The TM1 strains, although distinguishable, appeared similar to $K$. kingae and the Bijsterveld/Sutton strains in phenotypic characters, and the $\mathrm{G}+\mathrm{C}$ values of the TM1 strains were 5.4 to $6.1 \mathrm{~mol} \%$ higher than those of the Bijsterveld/Sutton strains. The saccharolytic species $C$. hominis appeared similar in its phenotypic characters to all of the saccharolytic strains, but its $\mathrm{G}+\mathrm{C}$ content was 4 to $6 \mathrm{~mol} \%$ higher than that of the TM1 strains and $10 \mathrm{~mol} \%$ higher than that of the Bijsterveld/Sutton strains. $E$. corrodens showed least similarity in phenotypic characters to all the other strains, and its $\mathrm{G}+\mathrm{C}$ content was $7 \mathrm{~mol} \%$ higher than that of the $K$. kingae and Bijsterveld/Sutton strains.

The separation of $K$. kingae, Bijsterveld/Sutton, and TM1 strains from moraxellas was supported by a comparison of the test results of the strains (Table 6). Absolute test differences between these strains and Moraxella species sensu stricto were the presence of saccharolytic activity, the failure to produce catalase, and the higher $\mathrm{mol} \% \mathrm{G}+\mathrm{C}$ values of these strains.

These results suggest that $K$. kingae, the Bijsterveld/Sutton strains, and the TM1 strains do not belong to the genus Moraxella. Although the DNA base composition of the TM1 strains is 5 mol \% G + C higher than that of the K. kingae and Bijsterveld/Sutton strains, there is no objective way of fixing limits on the range of $\mathrm{mol} \% \mathrm{G}+\mathrm{C}$ for a genus, and in view of the similarities in the phenotypic characters of the TM1, the $K$. kingae, and the Bijsterveld/Sutton strains, it is proposed that these three organisms be placed together in the same genus. Henriksen and Bøvre (12) recently argued the case for removal of $M$. kingae from the genus Moraxella and proposed the creation of a new 


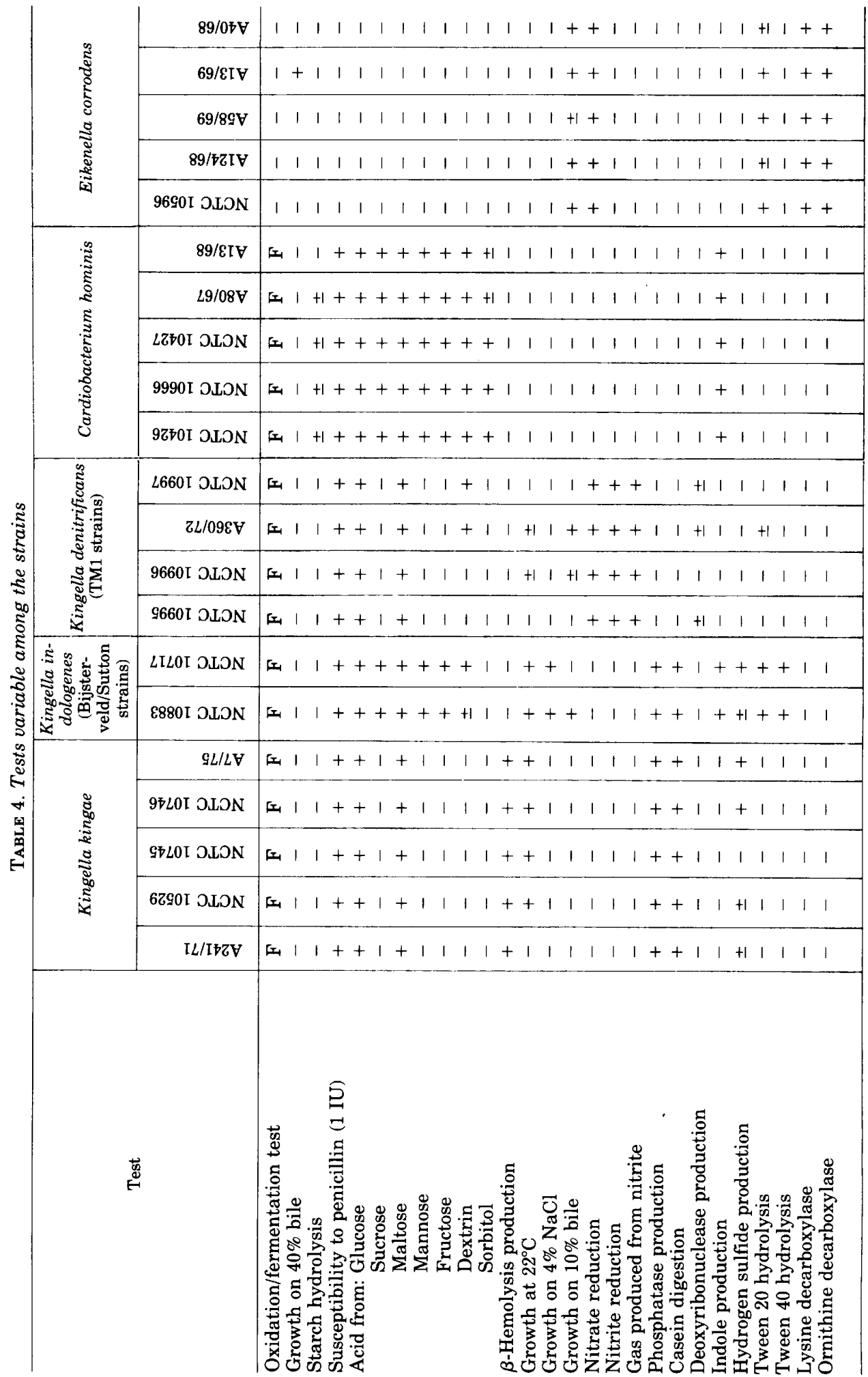


TABLE 5. DNA base compositions of saccharolytic strains and Moraxella species

\begin{tabular}{|c|c|c|}
\hline Strain & $T_{m}\left({ }^{\circ} \mathrm{C}\right)^{a}$ & $\mathrm{Mol} \% \mathrm{G}+\mathrm{C}$ \\
\hline \multicolumn{3}{|l|}{ Kingella kingae } \\
\hline NCTC 10529 & 89.98 & 47.3 \\
\hline NCTC 10745 & 90.03 & 47.4 \\
\hline NCTC 10746 & 90.05 & 47.4 \\
\hline \multicolumn{3}{|l|}{ Kingella indologenes } \\
\hline NCTC 10717 & 90.58 & 48.7 \\
\hline NCTC 10883 & 90.55 & 48.7 \\
\hline \multicolumn{3}{|l|}{ Kingella denitrificans } \\
\hline NCTC 10995 & 92.80 & 54.1 \\
\hline NCTC 10997 & 93.05 & 54.8 \\
\hline \multicolumn{3}{|l|}{ Cardiobacterium hominis } \\
\hline NCTC 10666 & 95.3 & 60.2 \\
\hline NCTC 10426 & 94.65 & 58.7 \\
\hline \multicolumn{3}{|l|}{ Eikenella corrodens } \\
\hline NCTC 10596 & 93.4 & 55.6 \\
\hline Moraxella bovis ( 2 strains) & $88.55-88.85$ & $43.8-44.5$ \\
\hline Moraxella equi (1 strain) & 88.85 & 44.5 \\
\hline $\begin{array}{l}\text { Moraxella lacunata (2 } \\
\text { strains) }\end{array}$ & $88.15-88.28$ & $42.8-43.1$ \\
\hline $\begin{array}{l}\text { Moraxella liquefaciens ( } 2 \\
\text { strains) }\end{array}$ & $88.65-88.9$ & $44.0-44.6$ \\
\hline $\begin{array}{l}\text { Moraxella nonliquefaciens ( } 2 \\
\text { strains) }\end{array}$ & $88.3-88.5$ & $43.2-43.7$ \\
\hline $\begin{array}{l}\text { Branhamella catarrhalis ( } 2 \\
\text { strains) }\end{array}$ & $87.75-87.8$ & $41.8-41.9$ \\
\hline $\begin{array}{l}\text { Branhamella cuniculi (1 } \\
\text { strain) }\end{array}$ & 88.88 & 44.6 \\
\hline Branhamella ovis (2 strains) & $89.45-89.58$ & $46.0-46.3$ \\
\hline $\begin{array}{l}\text { Branhamella caviae }(2 \\
\text { strains) }\end{array}$ & $89.73-90.0$ & $46.6-47.3$ \\
\hline Escherichia coli $\mathrm{K}-12$ & 91.51 & 51.0 \\
\hline
\end{tabular}

${ }^{a} T_{m}$ values are the mean of two determinations except that for $E$. coli $\mathrm{K}-12$, which is the mean of 11 determinations.

genus, Kingella, in the family Neisseriaceae Prévot 1933. Our findings support this proposal, and further we propose that two new species be included in the genus Kingella: $K$. indologenes (formerly the unnamed strains described by van Bijsterveld and Sutton et al.) and $K$. denitrificans (formerly the TM1 group of Hollis, Wiggins, and Weaver). The description of the family Neisseriaceae given by Reyn (21) gives the range of $\mathrm{G}+\mathrm{C}$ values as 39 to $52 \mathrm{~mol} \%$, and it is therefore necessary to amend the description by extending the range to 39 to $55 \mathrm{~mol} \% \mathrm{G}$ $+\mathrm{C}$.

Description of Kingella indologenes sp. nov.. (In. do. lo'ge. nes. M.L. noun indolum indole; Gr. v. gennaio to produce; M.L. part. adj. indologenes indole-producing.)

Synonym. None, but previously referred to as the "Bijsterveld/Sutton" strains $(1,24)$.

Gram-negative, nonmotile, plump rods, 1.0 $\mu \mathrm{m}$ in width, oxidase positive, and catalase negative. Small, translucent colonies are produced on blood agar after $48 \mathrm{~h}$ of incubation at $37^{\circ} \mathrm{C}$. Pitting of media or spreading edges of colonies may be present in freshly isolated strains, but this property may be lost on stor- age. Growth occurs anaerobically on blood agar. No hemolysis is produced on horse blood agar. Susceptible to $1 \mathrm{IU}$ of penicillin. $\mathrm{Mol} \% \mathrm{G}$ $+\mathrm{C}, 48.7$.

The following tests are positive: growth at 22,30 and $37^{\circ} \mathrm{C}$, fermentative result in the $\mathrm{O} /$ $\mathrm{F}$ test, acid production from glucose, maltose, sucrose, dextrin, fructose, and mannose, growth in the presence of $4 \% \mathrm{NaCl}$, phosphatase production, casein digestion, indole production, hydrogen sulfide production, and hydrolysis of Tweens 20 and 40 .

The following tests are negative: growth at 5 and $45^{\circ} \mathrm{C}$, growth in the presence of $6 \% \mathrm{NaCl}$, and $40 \%$ bile, stimulation of growth by bile, liquefaction of gelatin and serum, $\beta$-galactosidase production, citrate utilization, growth on $\beta$ hydroxybutyrate in mineral medium, poly- $\beta$ hydroxybutyrate granule production from $\beta$ hydroxybutyrate in nutrient medium, starch hydrolysis, urease production, Tween 80 hydrolysis, lecthinase production, nitrate reduction, nitrite reduction, deoxyribonuclease production, arginine hydrolysis, and production of ornithine and lysine decarboxylases. No acid produced from adonitol, arabinose, cellobiose, dulcitol, ethanol, galactose, glycerol, inositol, lactose, mannitol, raffinose, rhamnose, salicin, sorbitol, trehalose, or xylose.

Strains of this species varied in growth on $10 \%$ bile (type strain, negative).

Pathogenicity: Not known.

Type strain: NCTC 10717 (= American Type Culture Collection [ATCC] 25869).

Natural habitat: Not known. Isolated from eye infections.

Description of Kingella denitrificans sp. nov.. (De. ni. tri'fi. cans. L. prep. de away from; L. n. nitrum soda; M.L. n. nitrum nitrate; M.L. v. denitrifico denitrify; M.L. part. adj. denitrificans denitrifying.)

Synonym. None, but previously referred to as the "TM1" group of Hollis et al. (14).

Gram-negative, nonmotile, plump rods 1.0 $\mu \mathrm{m}$ in width, oxidase positive, and catalase negative. Small, translucent colonies are produced on blood agar after $48 \mathrm{~h}$ of incubation at $37^{\circ} \mathrm{C}$. Colonies may show pitting of the medium. Growth occurs anaerobically on blood agar. No hemolysis is produced on horse blood agar. Susceptible to $1 \mathrm{IU}$ penicillin. Mol\% G + $\mathrm{C}, 54.1$ to 54.8 .

The following tests are positive: growth at 30 and $37^{\circ} \mathrm{C}$, fermentative result in the $\mathrm{O} / \mathrm{F}$ test, acid production from glucose and maltose, nitrate reduction, nitrite reduction, and production of gas from nitrite.

The following tests are negative: growth at 5 and $45^{\circ} \mathrm{C}$, growth in the presence of 4 and $6 \%$ 


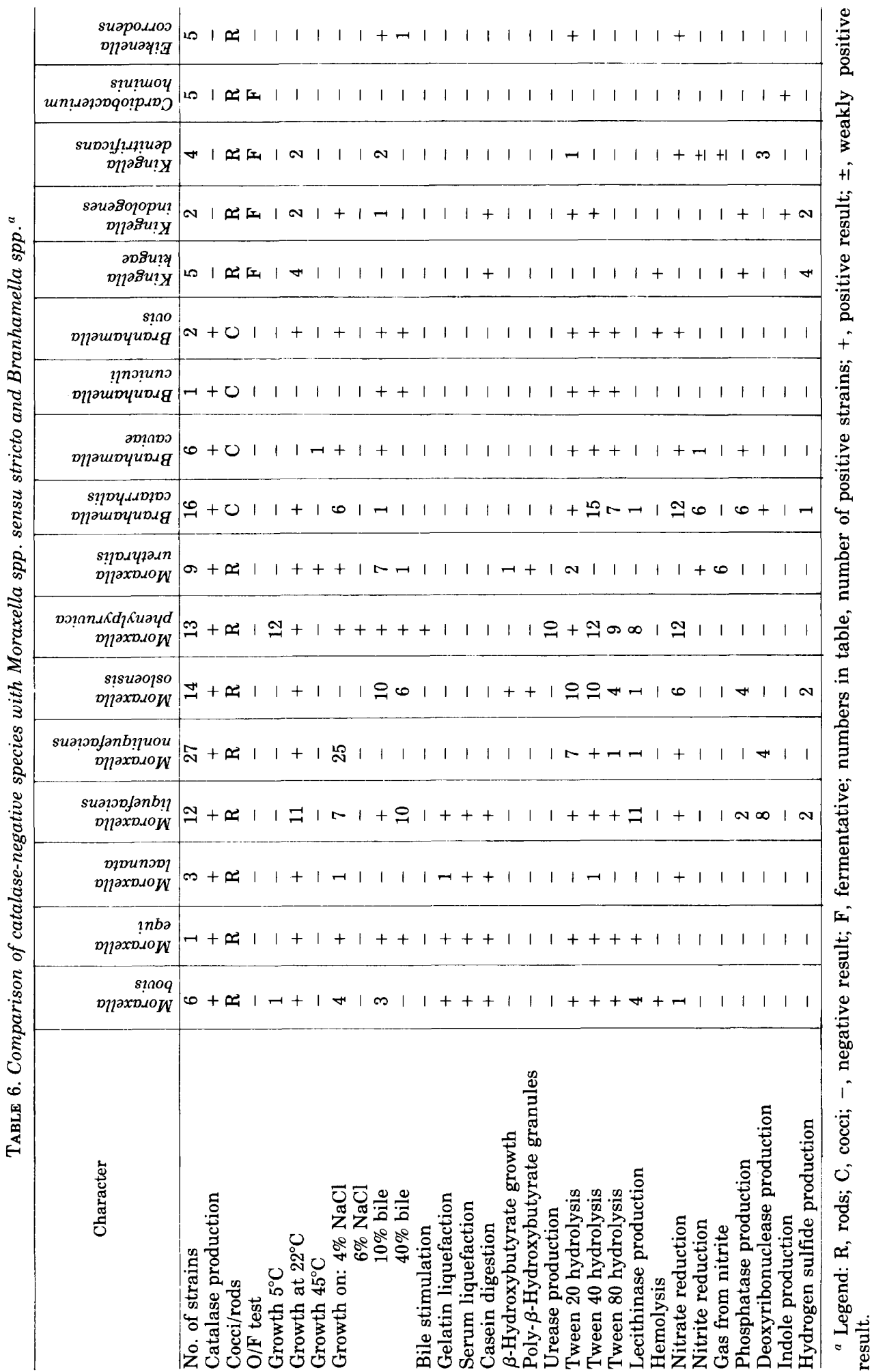


$\mathrm{NaCl}$ and $40 \%$ bile, stimulation of growth by bile, liquefaction of serum and gelatin, casein digestion, $\beta$-galactosidase production, citrate utilization, growth on $\beta$-hydroxybutyrate in mineral medium, poly- $\beta$-hydroxybutyrate production from $\beta$-hydroxybutyrate in nutrient medium, starch hydrolysis, urease production, hydrolysis of Tweens 40 and 80 , lecithinase production, phosphatase production, indole production, hydrogen sulfide production, and production of lysine and ornithine decarboxylases. No acid produced from adonitol, arabinose, cellobiose, dulcitol, ethanol, galactose, glycerol, inositol, lactose, mannitol, mannose, raffinose, rhamnose, salicin, sorbitol, sucrose, trehalose, or xylose.

Strains of this species varied in acid production from dextrin (type strain, negative), growth at $22^{\circ} \mathrm{C}$ (type strain, negative), growth on $10 \%$ bile (type strain, negative), deoxyribonuclease production (type strain, positive), and Tween 20 hydrolysis(type strain, negative).

Pathogenicity: Not known.

Type strain: NCTC 10995 (= Weaver's strain B 4363).

Found in the respiratory tract of man.

\section{REPRINT REQUESTS}

Address reprint requests to: Dr. S. P. Lapage, National Collection of Type Cultures, Central Public Health Laboratory, Colindale, NW9 5HT, London, England.

\section{LITERATURE CITED}

1. Bijsterveld, O. P. van. 1970. A new Moraxella strain isolated from angular conjunctivitis. Appl. Microbiol. 20:405-408.

2. Bøvre, K. 1970. Pulse-RNA-DNA hybridization between rodshaped and coccal species of the MoraxellaNeisseria groups. Acta Pathol. Microbiol. Scand. Sect. B 78:564-574.

3. Bøvre, K., M. Fiandt, and W. Szybalski. 1969. DNA base composition of Neisseria, Moraxella and Acinetobacter as determined by measurement of buoyant density in $\mathrm{CsCl}$ gradients. Can. J. Microbiol. 15:335338.

4. Bovre, K., J. E. Fuglesang, S. D. Henriksen, S. P. Lapage, H. Lautrop, and J. J. S. Snell. 1974. Studies on a collection of gram-negative bacterial strains showing resemblance to moraxellae: examination by conventional bacteriological methods. Int. J. Syst. Bacteriol. 24:438-446.

5. Bøvre, K., S. D. Henriksen, and V. Jonsson. 1974. Correction of specific epithet kingii in the combinations Moraxella kingii Henriksen and Bøvre 1968 and Pseudomonas kingii Jonsson 1970 to kingae. Int. J. Syst. Bacteriol. 24:307.

6. Brenner, D. J., G. R. Fanning, A. V. Rake, and K. E. Johnson. 1969. Batch procedure for thermal elution of DNA from hydroxyapatite. Ann. Biochem. 28:447-
459.

7. Chiu, M. S. Ho, and T. Lai. 1966. Description of a starch fermenting strain of Moraxella. Acta Microbiol. Sinica. 12:11-14.

8. Cowan, S. T. 1974. Cowan and Steel's manual for the identification of medical bacteria. University Press, Cambridge.

9. Flamm, H. 1956. Moraxella saccharolytica (sp.n.) aus dem Liquor eines Kindes mit Meningitis. Zentralbl. Bakteriol. Parasitenk. Infektionskr. Hyg. Abt. I. Orig. 166:498-502.

10. Henriksen, S. D. 1973. Moraxella, Acinetobacter, and the Mimeae. Bacteriol. Rev. 37:522-561.

11. Henriksen, S. D., and K. Bovre. 1968. Moraxella kingii sp. nov., a haemolytic saccharolytic species of the genus Moraxella. J. Gen. Microbiol. 51:377-385.

12. Henriksen, S. D., and K. Bøvre. 1976. Transfer of Moraxella kingae Henriksen and Bøvre to the genus Kingella gen. nov. in the family Neisseriaceae. Int. J. Syst. Bacteriol. 26:447-450.

13. Hill, L. R., J. J. S. Snell, and S. P. Lapage. 1970. Identification and characterisation of Bacteroides corrodens. J. Med. Microbiol. 3:483-491.

14. Hollis, D. G., G. L. Wiggins, and R. E. Weaver. 1972 An unclassified gram-negative rod isolated from the pharynx on Thayer-Martin medium (selective agar). Appl. Microbiol. 24:772-777.

15. Jackson. F. L., and Y. E. Goodman. 1972. Transfer of the facultatively anaerobic organism Bacteroides corrodens Eiken to a new genus, Eikenella. Int. J. Syst. Bacteriol. 22:73-77.

16. Lautrop, H. 1974. Genus III. Moraxella, p. 433-436. In R. E. Buchanan and N. E. Gibbons (ed.), Bergey's manual of determinative bacteriology, 8th ed. Williams and Wilkins Co., Baltimore.

17. Ley, J. de. 1970. Re-examination of the association between melting point, buoyant density, and chemical base composition of deoxyribonucleic acid. J. Bacteriol. 101:738-754.

18. Mandel, M., L. Igambi, J. Bergendahl, M. L. Dodson, and E. Scheltgen. 1970. Correlation of melting temperature and cesium chloride buoyant density of bacterial deoxyribonucleic acid. J. Bacteriol. 101:333338.

19. Marmur, J. 1961. A procedure for the isolation of deoxyribonucleic acid from micro-organisms. J. Mol. Biol. $3: 208-218$

20. Marmur, J., and P. Doty. 1962. Determination of the base composition of deoxyribonucleic acid from its thermal denaturation temperature. J. Mol. Biol. 5:109-118

21. Reyn, A. 1974. Family I. Neisseriaceae, p. 427-438. In R. E. Buchanan and N. E. Gibbons (ed.), Bergey's manual of determative bacteriology, 8th ed. Williams and Wilkins Co., Baltimore.

22. Slotnick, I. J., and M. Dougherty. 1964. Further characterization of an unclassified group of bacteria causing endocarditis in man: Cardiobacterium hominis gen. et sp. n. Antonie van Leeuwenhoek J. Microbiol. Serol. 30:261-272.

23. Snell, J. J. S., L. R. Hill, and S. P. Lapage. 1972. Identification and characterization of Moraxella phenylpyruvica. J. Clin. Pathol. 25:959-965.

24. Sutton, R. G. A., M. F. O'Keeffe, M. A. Bundock, J. Jeboult, and M. P. Tester. 1972. Isolation of a new Moraxella from a corneal abscess. J. Med. Bacteriol. 5:148-150 